\title{
Walking into the Footprint of EU Law: Unpacking the Gendered Consequences of Brexit
}

\author{
Roberta Guerrina* and Annick Masselot** \\ * University of Surrey \\ E-mail: r.guerrina@surrey.ac.uk \\ ** University of Canterbury, New Zealand \\ E-mail: annick.masselot@canterbury.ac.nz
}

This article explores the gendered nature of the process of withdrawing from the European Union. Considering the EU is widely accepted as a gender actor, particularly in the context of employment policy, the marginality of these issues in current debates reflects a hierarchy in the value attributed to different policy areas that crystallizes the high-low politics binary. European led initiatives have undoubtedly changed the nature of equality policies in the Member States. Recent studies have also outlined how, and to what extent, EU policy contributes to shifts in gender regimes, gender policy and gender relations at the national level. Women in the UK have benefited greatly from membership of the EU/EEC; thus, looking at Brexit as a process provides a unique opportunity to reflect on the relationship, and patterns of influence, between European and national legislation.

Keywords: EU gender politics, Brexit, maternity rights, women on boards.

\section{Introduction}

The public debate during the EU referendum campaign and the British government's opening position on the Brexit negotiations highlight an overarching blindness to how embedded the European acquis has become within the British social model. Exiting the EU carries a substantial risk to the interests of traditionally marginal groups (including women) who have hitherto been covered by the EU legal framework since the UK joined the European Economic Community (EEC) in 1973. Questions therefore need to be asked about how the process of exiting the EU will ensure that these rights are safeguarded and embedded in new UK law. The European Union (Withdrawal) Bill [HC] (Bill 5, 201719, UK Parliament, 2017) sets out how powers and legal responsibilities/rights will be repatriated from the EU to the UK post-Brexit. It also sets out the powers of the government to legislate at the expense of parliamentary scrutiny. This indicates that authority will be concentrated in the hands of the political executive, which will have the ability to reshape legal principles in relation to key social legislation, potentially to detrimental effect on marginal groups and women (Syrpis, 2017). Moreover, the House of Commons vote in November 2017, against the amendments to the Bill aimed at safeguarding the rights established under the 2010 Equality Act, highlights the direction of travel under the May government.

This article explores the gender implications of Brexit by mapping the extent to which UK gender equality legislation is grounded in EU social law. The main research 
question underpinning this article is: Will the process of exiting the EU impact on the gender equality principle within UK law? Related to this question, we will also explore the following sub-questions: Is it possible to identify the emerging characteristics of the post-Brexit gender regime? Are there identifiable guarantees for UK gender equality law that will safeguard current provisions once the EU 'safety-net' is withdrawn? In other words, we aim to assess if the process of Brexit might have a detrimental impact on gender equality policies. We recognise this is a difficult task. We will therefore look back to the performance of UK governments in the negotiations of two core policy areas at the European level - namely, maternity rights and gender diversity in economic leadership in order to establish UK government's priorities in a post-Brexit environment. This analysis will unpack how the UK's position influenced the outcome and the principles that became embedded within those same policies as indicators of the government's political priorities and the gender ideology/regime at work in a post-EU membership environment. Our core assumption is that the greater the reliance on EU provisions for the development of national legislation, the greater the impact of Brexit on national policies. This analysis tackles one of the most significant and pervasive silences of current discussions about the UK's future relationship with the EU, thus shining a light on the marginalisation of gender, equality, and social cohesion in this increasingly fraught process.

\section{Gendering Brexit: silences and silos in discussion on exiting the EU}

Recognition that gender and equality were left out of public debates and discourse during the EU referendum campaign raises important questions about silences during the negotiations, and the impact these will have on a post-Brexit settlement (Guerrina and Murphy, 2016; Hozić and True, 2017). The starting point of our analysis is the overwhelming evidence of the gendered impact of austerity as a platform for understanding the impact of exiting the EU on gender equality policies in the UK. The recent economic crisis and associated austerity policies have weakened women's position in the public sphere and the official labour market. Key services aimed at women's activation have been depleted by various rounds of austerity measures. The discourse of crisis allowed policy makers to side-line gender equality in the pursuit of higher political and economic priorities. Perhaps more significantly, this narrative helped to legitimise cuts to services that enable women's participation in the labour market, thus compounding the impact of austerity on traditionally marginal groups (Karamessini and Rubery, 2014; Walby, 2015; Guerrina, 2017; Emejulu and Bassel, 2017). As Kantola and Lombardo's (2017: 12) extensive exploration into the gendered nature of crisis highlights, the policy responses to the economic crisis have helped to sideline key gender actors within European institutions ultimately, undermining the ability of feminist policy agencies to mainstream gender into all policy areas, including the economic and Brexit.

The process of withdrawing from the $\mathrm{EU}$ is going to pose a number of economic and legal challenges for the UK, which will have an impact on the shape of social policy, and particularly the gender equality legal framework. It is difficult to forecast the full extent of this process on gender equality policies in the UK. However, looking at the silences in the debates before the EU referendum and the dominant policy discourse since the triggering of Article 50 in March 2017, it is possible to make some inductive prognosis. As Hozić and True (2017: 217) argued the process of withdrawing from EU membership has been extensively defined by 'the paradox of men's dominance of the Brexit campaign 
and women's rise in the political crisis that ensued after the referendum vote. Women have become visible actors in Brexit ostensibly to "clean up" the mess left by their male counterparts'. They take this analysis deeper, drawing attention to the wider political and economic processes that enabled the discourse of Brexit to take root and that will ultimately crystallise structures of power and inequality within British society.

There is substantial evidence, and an established body of literature, about the impact of European norms on the development of the gender equality principle in the UK (e.g. Guerrina, 2005; Kantola, 2010; Woodward and van der Vleuten, 2014). The way the EU has developed gender equality policies, the range of practices and actors involved in the policy process, and the impact on equality outcomes, mean that the EU itself is emerging as a gender regime in its own right (Walby, 2004). The scaffolding provided by the Treaty foundations, legally binding measures, and soft policy initiatives has allowed EU gender equality policies to have significant reach within the Member States (Kantola and Nousiainen, 2012; Woodward and van der Vleuten, 2014). Moreover, the ability of European institutions to sidestep Member States' opposition in order to promote the principle of (formal) equality has ensured the institutionalisation of a fairly comprehensive safety-net for women's rights across Europe. This Europeanisation of gender equality policies draws attention specifically to the impact of the gender equality acquis on the development of this policy portfolio at the national level (Forrest and Lombardo, 2012). Understanding the balance between the $\mathrm{EU}$ as an economic actor and as a gender actor is therefore key to understand the long term impact of Brexit on gender equality policies in the UK.

A couple of points are worth highlighting here. Although the principle of equality has become reified as a foundation myth of European integration (MacRae, 2010), the European equality agenda is highly commodified with a distinct economic flavour. Indeed, the principle of gender equality was included into the Treaty of Rome in order to safeguard fair competition in the newly established Common Market (Kantola, 2010; Bain and Masselot, 2013). Moreover, the focus on activation and formal equality has contributed to bypass difficult discussions about gender justice and structural obstacles to achieving substantive equality.

The UK became member of the EEC on 1st January 1973, at a time of expansion of the gender equality acquis. It therefore had a significant influence on the establishment of the European gender regime. The relationship between the UK and the EU should not be seen as unidirectional (see Hantrais, 2018). There is clear evidence of the impact of European legislation on the development of national equality policies, specifically when the Conservative party held power (Annesley and Gains, 2013). However, the UK bias in favour of de-regulation also filtered into the negotiations, limiting the scope of key policy initiatives, e.g. the 1992 Pregnant Workers Directive.

Against this background, the UK's withdrawal from the EU has to raise important questions about the future development of gender equality policies in face of a (Conservative) government that is seeking to consolidate power in the hands of the executive. In order to understand the potential traps facing women's rights advocates and future trajectory of gender equality policies, we need to explore the UK government position, and priorities, during the negotiations of core policies that are known to have had a significant impact on national provisions. As Hix et al. (2016) have outlined, between 2009 and 2015 the UK has tended to vote against the majority of Member States in matters of employment and social affairs. The next two sections will therefore focus on the 
Pregnant Workers Directives and the Proposed Directive for Gender Balance in Corporate Boards to show that post-EU membership, gender equality rights in the UK are very likely to backslide, or at the very least to progress more slowly than in the EU. These policy areas were selected as examples of the UK's performance at the European level in the area of social affairs, in relation to the juxtaposition of business interests and gender equality.

\section{The Pregnant Workers Directives: understanding the role of competing interests}

The EU's role as a gender actor has not lived up to feminists' expectations. Equality is one of its fundamental values, but there is a growing gulf between rhetoric and reality (MacRae, 2010). The kind of equality agenda produced has been largely driven by economic imperatives (see Fagan and Rubery, 2017 and Plomien, 2018). Nevertheless, it has produced a body of legislation that normalised the idea of gender equality in the labour market. Moreover, it has provided a platform for feminist organisations to lobby beyond the Member States. It has also given space to Femocrats (feminist bureaucrats dealing with women's issues) to promote far reaching legislation in a number of areas, including pregnancy protection (Woodward, 2003; Abels and MacRae, 2016).

Our first case shows how the business interests of UK employers has tended to take primacy over pregnancy and maternity rights (Caracciolo di Torella and Masselot, 2001; Guerrina and Murphy, 2016). Before the adoption of the 1992 Pregnant Workers Directive, the UK applied a formal regime of sex equality, which required that a comparator be used in cases of sex discrimination. However, it was understood for a long time that there could be no claim of sex discrimination on the grounds of pregnancy because there could be no comparison with other workers, as men could not become pregnant. Employers could therefore dismiss pregnant workers unchallenged with regards to sex discrimination. The case Turley v. Allders Department Stores [1980] IRLR 4 only changed this perspective in that it allowed pregnant workers to be compared to ill workers, which also permitted employers to justify the dismissal of pregnant workers on the ground of productivity (see Lacey, 1987; MacKinnon, 1998). This was later confirmed in Hayes v. Malleable Working Men's Club And Institute [1985] IRLR 367, whereby it was accepted that pregnant women could be compared to similarly situated men who were temporarily sick. The UK's position to compare pregnant women with the situation of ill men shows that the business interest was embedded into employment law in a way that it excluded women's reproductive rights. Moreover, the primacy of business interest over women's rights, human rights and other trade union's rights is a direct consequences of the application of the Common Law (Anderson, 2016).

The adoption of the Pregnant Workers Directive has acted as a catalyst for the development of pregnancy and maternity rights in the UK (Guerrina, 2005; Masselot et al., 2012). Nevertheless and despite the fact that the Pregnant Workers Directive imported significant legal rights for women in the British workplace, the underlying supremacy of the business interest has continued to play a crucial role in shaping national reproductive rights. This is best illustrated by the negotiations leading up to the ratification of the Pregnant Workers Directive, implementation and the application of this Directive at national level (see for instance the Webb case) as well as the UK influence over the demise of the 2008 proposed amendment to the Pregnant Workers Directive (Guerrina, 2005; Masselot et al., 2012). The negotiations that surround both policy proposals in 
particular highlight the tension between establishing a minimum threshold of rights for working mothers and the interest of the business (Guerrina, 2005; PA, 2011; Eurofund, 2015).

\section{The negotiations of the Pregnant Workers Directive}

The negotiations surrounding the introduction of the 1992 Directive highlights the UK's activism against the expansion of reproductive rights in employment law. A very ambitious proposal for the protection of pregnancy and maternity rights had originally been drafted by the European Commission. However, the UK was particularly vocal in its opposition to this draft proposal. The UK objected that the proposal was going to be too costly for employers. In order to prevent opposition in the Council, the Commission revised and watered down its original proposal (Guerrina, 2005). Moreover, while the original proposal was conceived as an equality measure, under the auspices of Article $119 \mathrm{EC}$ (now Article 157 TFEU), the Directive was ultimately adopted on the basis of health and safety under Article 118a EC (now Article 153 TFEU). The switch of legal foundation was justified in order to bypass the requirement for unanimity voting of equality provisions in the Council. Health and safety provisions at the time had only to be decided by qualified majority voting. The UK government's opposition to the directive represented one of the main reasons for changing the focus of the Directive and watering down its scope. In so doing, the Commission and the European Parliament (EP) ensured the adoption of a minimum standard of protection for pregnant workers and workers who recently gave birth. However, it also highlights how the minimum EU standard in pregnancy and maternity rights was defined and dragged down by the UK, at the end only representing a mere safety-net (Guerrina, 2005; van der Vleuten, 2007; Bego, 2015).

\section{The implementation and the application of this Directive at national level}

Article 10 of the Pregnant Workers Directive prohibits the dismissal of a pregnant worker from the moment she is pregnant until the end of the period of maternity leave. Article 11 of the Directive also protects pregnant workers against forms of employment discrimination during this same period. The Court of Justice of the EU had moreover clarified the scope of this protection in Dekker (Case 177/88) which considered the situation where a qualified (pregnant) applicant to a job was not appointed because business-cost related to her pregnancy would have been too heavy for the employer. The Court held that, 'as employment can only be refused because of pregnancy to women', discrimination on the grounds of pregnancy is direct sex discrimination, which cannot be justified even on the basis of cost to the business (Caracciolo di Torella and Masselot, 2001). This principle was confirmed in Hertz (Case 179/88) with respect to the dismissal of a pregnant worker. Regardless of the very clear legal requirement, the UK has nevertheless continued to push back against this principle and to promote instead the interest of the business. In Webb (Case C-32/93), the House of Lords considered the dismissal of a pregnant worker who had been employed in order to replace a worker who had taken maternity leave and held that the dismissal of the pregnant worker could be justified on the basis of the employer's interest. ${ }^{1}$ In contrast, on a preliminary ruling, the European Court of Justice re-stated the principle that no comparison can be made between the situation of a woman incapable of working due to pregnancy and a man similarly incapable for medical or other reasons. 
Pregnancy is not a pathological condition comparable to non-availability for work on non-medical grounds, which would otherwise justify dismissal without discrimination on grounds of sex (Boch, 1998; Caracciolo di Torella and Masselot, 2001).

\section{The negotiations over the amendments of the Pregnant Workers Directive}

Over a decade after the implementation of the Pregnant Workers Directive, the Commission proposed to re-open the question in an attempt to improve working standards for pregnant workers across Europe. The negotiations of this proposed second directive, however, highlight the enduring neo-liberal bias in the UK's position on regulating employment rights.

In October 2008, the European Commission adopted a Work-Life Balance Package made up for four key documents: a Communication on Work-Life Balance, proposals to amend the Pregnant Worker Directive $(\operatorname{COM}(2008) 637)$ and the Self-Employed Directive (COM(2008) 636), and a monitoring system of member states' progress towards meeting the Barcelona Childcare Targets (EC, 2008a-d). Of particular interest here was the legislative proposal to revise the existing Pregnant Workers Directive 92/85/EEC by extending pregnancy and maternity rights in several areas. The proposed directive operated a shift of focus from health and safety to equality. Specific amendments were centred on five areas: length and modality of the period of maternity leave (from fourteen to eighteen weeks), the level of payment, the protection against dismissals, the possibility to return to the same job and possibility to request flexible working arrangements. In addition the proposed directive contained a number of provisions common to all the 'new generation' equality Directives, including provisions on the reversal of the burden of proof, protection against retaliation and victimisation, the prohibition of upper limits on compensation, and the competence of national equality bodies on issues pertaining to equal treatment but not health and safety.

Although the Commission's proposal to amend the Pregnant Workers Directive addressed a number of the present legislation's shortcomings, it also fell short of implementing a comprehensive gender equality framework. In particular, if the legal base extended the ratione materiæ of the Pregnant Workers Directive, it did not alter its ratione personæ: indeed the proposed directive continued to be addressed exclusively to women in their occupational capacity. Moreover, the proposed directive included discrepancies amongst employed women, as access to some of the rights (such as pay) continued to require a minimum level of continuity in employment. For instance, in order to qualify for paid maternity leave, a worker was required to have been continuously employed for a period of six months prior to confinement. This was likely to have the effect of excluding certain categories of workers, such as those employed in atypical forms of employment. Arguably these workers are in the most precarious positions, in need of even more protection than workers who have a permanent position. The link between employment and pregnancy and maternity rights was therefore always questionable (Callister and Galtry, 2009) and undermined the fundamental right element which was supposed to underpin the proposed directive.

In its first reading the European Parliament expanded further the Commission's proposal. In particular, the EP broadened the entitlement to a continuous period of maternity leave to at least twenty weeks allocated before and/or after confinement, extending the Commission's proposal of eighteen weeks and the fourteen weeks set out 
in the 1992 Directive. This time expansion was justified as compatible with the World Health Organisation recommendation that mothers breast feed babies until the age of six months. Furthermore, the EP proposed to include a compulsory period of six weeks maternity leave after birth on full pay, without infringing upon existing national laws which provide for a period of compulsory paid maternity leave before childbirth. The six-weeks period of compulsory paid maternity leave was to apply to all working women, regardless of their existing continuous period of employment (European Parliament, 2009).

The polarized disagreement between the Parliament and Council resulted in a stalemate that ultimately led to the formal withdrawal of the Directive on 1 July 2015. The issues of the length and the level of payment of the period of maternity leave became the central 'battleground' for discussions between representatives of the Council on the one hand and the European Parliament on the other. While the EP asserted the interests of citizens, the Council put forward a narrow framing of national interest led by a number of member states, including the UK. Referring to the Global Financial Crisis, representatives of the member states voiced concern over prospective financial costs and argued that the proposal placed undue economic burdens on national economies already weakened. In addition to cost, the debate around the optimal length of the maternity leave was framed by the representatives in the Council around the attachment of women into the labour market. A short maternity leave is considered to reduce the risks of women not returning to the paid labour market and its impact on the economic growth. By contrast, children's health, parental choice and work-family reconciliation were seldom raised and only by the EP. Gender equality thus, was understood unidimensionally as female access and attachment to the labour market. The Council's exclusive concern with raising women's employment rate too often results in women mimicking the male standard of work or, worse yet, the 'unencumbered worker' (James, 2007, 2008; Daly, 2011). Bringing back the debate to the national level, some states argued that their existing policy was more efficient than the proposed directive. The UK, in particular, released a series of impact assessments stating the domestic regulation of the length of time and payment of maternity leave was adequate and satisfactory (HM Government, 2012, 2012a, 2012b, 2012c).

\section{Proposed directive for gender balance in corporate boards}

Not only the UK government and the British Courts have opted for a gender regime which favours business over women's rights, but industry is also unsympathetic to introducing regulations to challenge gender inequity. UK industry appears to be willing to keep the status quo which is fiercely discriminatory to women, in contrast to other jurisdictions such as Australia and Finland, where industry has taken an active stance to input equity standards (Masselot and Brand, 2015). While the UK's position has restrained the EU's ability to develop gender equality regulations, the exit of the UK from the EU also means that the British equity standards are likely to collapse without the EU minimum standards. This is best illustrated with the development of regulation over gender balance on corporate boards.

The EU has been interested in redressing the glass ceiling in the corporate world for some time. In 2011, the EU Commissioner for Justice and Fundamental Rights, Viviane Reding, launched Women on the Board Pledge for Europe, calling on large companies to increase women's presence at the board level to 30 per cent by 2015 and to 40 per cent by 2020 (Reding, 2011). Reding promised to consider legislative action if the 
self-regulatory initiative did not produce results by March 2012. As results did not improve, the Commission adopted in 2012 a proposal for a directive (COM (2012) 614) designed to set up a series of measures to improve the gender balance among non-executive directors of companies listed on stock exchanges (EC, 2012). The goal of the proposed directive (COM (2012) 614) is:

to ensure a more balanced representation of men and women among the non-executive directors of listed companies by establishing measures aimed at accelerated progress towards gender balance while allowing companies sufficient time to make the necessary arrangements. (Article 1)

Expecting resistance from the UK in particular, the Commission's proposal was weak (Masselot and Maymont, 2015), only requiring Member States to aim to improve appointment procedures, so that, by 2020, a minimum proportion of 40 per cent of company board members of publicly listed companies would belong to the underrepresented sex (Article 4.1). The sanctions for breach of the obligation would merely be an administrative fine (Article 4.3). The proposed directive would exempt a large number of companies from the obligation, including listed companies where members of the under-represented sex represent less than 10 per cent of the workforce (Article 4.6) and listed companies which could show that members of the under-represented sex would hold at least one third of all director positions, irrespective of their status as executive or non-executive (Article 4.7).

The UK had been voicing opposition to the adoption of regulation encouraging corporate diversity, favouring instead a self-regulatory approach which would make it mandatory for certain companies to disclose the gender composition of their boards in the hope that this increased visibility would lead to pressure from stakeholders to improve gender balance (Fagan et al., 2012).

As gender balance in corporate boardrooms had been raised as a concern in the context of the global financial crisis, the UK Government commissioned the Lord Davies report (2011), which noted that only 12.5 per cent of FTSE board directorships were held by women and made several recommendations for self-regulation with a view to increase the proportion of female directors to 25 per cent by 2015 (Davies, 2011). The Lord Davies' target of 25 per cent by 2015 has remained a distant and unachieved prospect (Sealy and Vinnicombe, 2013).

While the voluntary approach was the essence of the Davies report, it stressed that 'the Government must reserve the right to introduce more prescriptive alternatives if the recommended business-led approach does not achieve significant change' (Davies, 2011). Alluding to the possibility of a quota, Prime Minister David Cameron remarked in 2012 that, 'having strong measures will not be taboo anymore' if women's representation did not improve (Arthur, 2012). Such a statement was undoubtedly significant for a conservative Prime Minister, and could be construed as an objective expression of the potential merits of a quota as opposed to mainstream party rhetoric. However, since these statements were made, little has happened in this area. Self-regulation has only worked in countries where there has been strong industry commitment such as Australia and Finland (Masselot and Brand, 2015). The UK financial sector has firmly stopped the adoption of any equity standards in their track and the UK government has not demonstrated any ability to push back against the financial industry. 


\section{Conclusions: Brexit through the looking glass}

The two examples analysed in this article highlight that in a post-EU membership environment, British women will find themselves deprived of EU advocacy for gender equality. In both cases, representatives of the UK government deployed the business argument in order to stop the ratification of new gender equality policies. They highlight that economic and business interests have prime position in the way the UK has pursued its economic policy at the European Union level. The main lesson from austerity/crisis is that the prospect of a new 'crisis' is likely to cement government's business centred priorities at the expense of gender equality.

In order to understand how withdrawing from EU membership will affect the future trajectory of UK gender equality law, it is necessary to trace the relationship between the development of national equality legislation and EU law, both hard and soft policies. Annesley and Gains (2013) identified a clear trend in the last forty years whereby most developments in gender equality legislation in the UK have either been the result of European requirements or of key initiatives by the Labour government. The consideration of UK past behaviour helps us to understand continuity and change in government priorities in relation to $\mathrm{EU}$ and gender equality policies.

The case of the Pregnant Workers Directive illustrates how the UK's withdrawal from the EU is likely to impact on British women's reproductive rights. As production remains more valued than reproduction, the interests of business are likely to trump over other fundamental principles, e.g. equality. Advocacy for women's access to pregnancy and maternity rights are likely to become quickly and deeply eroded. British women will lose representation in the EP as well as through transnational networks of organised civil society. Women's advocacy groups will no longer be able to draw on powerful allies within European institutions to hold member states accountable. It is unlikely that those losses can be mitigated by domestic advocacy, as the recent austerity period shows that business interests are likely to take front stage unchallenged. The case of diversity in corporate decision making also shows that concentration of power in the executive branch, reification of economic drivers as an indicator of success, and the dogma of removing 'red tape', pose a real challenge to the very foundations of equal opportunities policies. As the UK government seeks to find a suitable way forward through the negotiation process and adapts to the post-Brexit settlement, it is likely to be increasingly difficult for civil society organisations to keep the issue of gender equality on the agenda, particularly as the government's focus will be on ensuring the economic position of the country.

\section{Note}

1 As per by Glidewell L.J. in the Court of Appeal decision of Webb v. EMO Cargo (UK) Ltd. [1992] Common Market Law Review 793.

\section{References}

Abels, G. and MacRae, H. (2016) Gendering European Integration Theory - Engaging New Dialogues, New York: Columbia University Press.

Anderson, G. (2016) 'The common law and the reconstruction of employee relationships in New Zealand', International Journal of Comparative Labour Law and Industrial Relations, 32, 93-116. 
Annesley, C. and Gains, F. (2013) 'Investigating the economic determinants of the UK gender equality policy agenda', The British Journal of Politics and International Relations, 15, 3, 125-46.

Arthur, C. (2012) 'EU plans tough quotas to put women in the boardroom', The Guardian, 4 March, https://www.theguardian.com/business/2012/mar/04/women-europe-plans-boardroom-quotas [accessed 08.11.2017].

Bain, J. and Masselot, A. (2013) 'Gender equality law and identity building for Europe', Canterbury Law Review, 18, 99-120.

Bego, I. (2015) Gender Equality Policy in the EU: A Fast Track to Parity for New Member States, Basingstoke: Palgrave.

Boch, C. (1998) 'Où s'arrête le principe d'égalité ou de l'importance d'être bien-portante: à propos de I'arrêt Larsson de la Cour de Justice', Cahiers de Droit Européen, 177-90.

Callister, P. and Galtry, J. (2009) 'Baby bonus" or paid parental leave - which one is better?', Social Policy Journal of New Zealand, 34, 1, 1-11.

Caracciolo di Torella, E. and Masselot, A. (2001) 'Pregnancy, maternity and the organisation of family life: an attempt to classify the case law of the Court of Justice', European Law Review, 26, 3, 239-60.

Case 177/88, Elisabeth Johanna Pacifica Dekker v Stichting Vormingscentrum voor Jong Volwassenen (VJV-Centrum) Plus [1990]ECR I-3941.

Case 179/88, Handels- og Kontorfunktionaerernes Forbund i Danmark v Dansk Arbejdsgiverforening (Hertz) [1990]ECR 1-3979.

Case C-32/93, Carole Louise Webb v EMO Air Cargo (UK) Ltd. [1994]ECR I-3567.

Daly, M. (2011) 'What adult worker model? A critical look at recent social policy reform in Europe from a gender and family perspective', Social Politics: International Studies in Gender, State and Society, $18,1,1-23$.

Davies, E. (2011) Women on Boards, http://www.boardsforum.co.uk/pdf/womenonboards2011.pdf, [accessed 08.11.2017].

Emejulu, A. and Bassel, L. (2017) 'Whose crisis counts? Minority women, austerity and activism in France and Britain, in J. Kantola and E. Lombardo (eds.), Gender and the Economic Crisis in Europe: Politics, Institutions and Intersectionality, Basingstoke: Palgrave, 185-208.

Eurofund (2015) Commission Withdraws Proposal to Extend Maternity Leave, Promising a Fresh Start - Developments at EU Level - Q2 2015, http://www.eurofound.europa.eu/printpdf/observatories/ eurwork/articles/working-conditions-law-and-regulation/commission-withdraws-proposal-to-extendmaternity-leave-promising-a-fresh-start-developments-at-eu [accessed 07.11.2016].

European Commission (EC) (2008a) Communication from the Commission: A Better Work-Life Balance: Stronger Support for Reconciling Professional, Private and Family Life, COM(2008) 635, Brussels: EC.

European Commission (EC) (2008b) Implementation of the Barcelona Objectives Concerning Facilities for Pre-School-Age Children, COM (2008) 638, Brussels: EC.

European Commission (EC) (2008c) Proposal for a Directive amending Council Directive 92/85/EEC on the Introduction of Measures to Encourage Improvements in the Safety and Health at Work of Pregnant Workers and Workers who have Recently given Birth or are Breastfeeding, COM(2008) 637, Brussels, EC.

European Commission (EC) (2008d) Proposal for a Directive on the Application of the Principle of Equal Treatment between Men and Women Engaged in an Activity in a Self-Employed Capacity and Repealing Directive 86/613/EEC, COM(2008) 636, Brussels, EC.

European Commission (EC) (2012) Proposal for a Directive of the European Parliament and of the Council on Improving the Gender Balance among Non-Executive Directors of Companies Listed on Stock Exchanges and Related Measures, 14 November, COM(2012) 614 final, Brussels, EC.

European Parliament (EP) (2009) Report on the Proposal for a Directive of the European Parliament and of the Council Amending Council Directive 92/85/EEC on the Introduction of Measures to Encourage Improvements in the Safety and Health at Work of Pregnant Workers and Workers who have Recently Given Birth or are Breastfeeding, 23.04.2009, (2008/0193(COD)), Brussels: EP. 
Fagan, C., González Menéndez, M. and Gómez Ansón, S. (2012) (eds) Women on Corporate Boards and in Top Management: European Trends and Policy, Basingstoke: Palgrave MacMillan.

Fagan, C. and Rubery, J. (2017) 'Advancing Gender Equality through European Employment Policy: The Impact of the UK's EU Membership and the Risks of Brexit', Social Policy \& Society, doi:10.1017/S1474746417000458.

Forrest, M. and Lombardo, E. (2012) 'The Europeanisation of gender equality policies a discursive sociological approach', in E. Lombardo and M. Forrest (eds.) The Europeanisation of Gender Equality Policies: a Discursive Sociological Approach, Basingstoke: Palgrave MacMillan, $1-27$.

Guerrina, R. (2005) Mothering the Union: Gender Equality Politics in the EU, Manchester: Manchester University Press.

Guerrina, R. (2017) 'Gendering European economic narratives: assessing the costs of the crisis to gender equality', in J. Kantola and E. Lombardo (eds.), Gender and the Economic Crisis in Europe: Politics, Institutions and Intersectionality, Basingstoke: Palgrave MacMillan, 95-116.

Guerrina, R. and Murphy, H. (2016) 'Strategic silences in the Brexit debate: gender, marginality and governance', Journal of Contemporary European Research, 12, 4, 872-80.

Hantrais, L. (2018) 'Review Article: Assessing the Past and Future Development of EU and UK Social Policy', Social Policy \& Society, doi:10.1017/S14747417000483.

Hix, S., Hagemann, S. and Frantescu, D. (2016) 'Would Brexit matter? The UK's voting record in the Council and the European Parliament', VoteWatch Europe, Brussels, http://www.votewatch.eu [accessed 11.11.2017].

HM Government (2012) Consultation on Modern Workplaces: The Parental Leave (EU Directive) Regulations 2013 - Impact Assessment, BIS/12/1285, https://www.gov.uk/government/uploads/ system/uploads/attachment_data/file/82797/12-1285-parental-leave-regulations-2013-impact.pdf [accessed 08.11.2017].

HM Government (2012a) Consultation on Modern Workplaces - Government Response - Equality Impact Assessment (EQIA) on Flexible Parental Leave and Flexible Working, BIS/12/1271, https://www.gov.uk/government/uploads/system/uploads/attachment_data/file/82795/12-1271modern-workplaces-response-equality-impact-on-flexible.pdf [accessed 08.11.2017].

HM Government (2012b) Consultation on Modern Workplaces - Government Response on Flexible Working: Impact Assessment, BIS/12/1269, https://www.gov.uk/government/uploads/system/ uploads/attachment_data/file/82793/12-1269-modern-workplaces-response-flexible-working.pdf [accessed 08.11.2017].

HM Government (2012c) Consultation on Modern Workplaces - Government Response on Flexible Parental Leave - Impact Assessment, BIS/12/1271, https://www.gov.uk/government/uploads/system/ uploads/attachment_data/file/82795/12-1271-modern-workplaces-response-equality-impact-onflexible.pdf [accessed 08.11.2017].

Hozić, A. and True, J. (2017) 'Brexit as a scandal: gender and global trumpism', Review of International Political Economy, 24, 2, 270-87.

James, G. (2007) 'Law's response to pregnancy/workplace conflicts: a critique', Feminist Legal Studies, 15, $2,167-88$.

James, G. (2008) The Legal Regulation of Pregnancy and Maternity in the Labour Market, Cavendish: Routledge.

Kantola, J. and Lombardo, E. (2017) (eds.) Gender and the Economic Crisis in Europe: Politics, Institutions and Intersectionality. Basingstoke: Palgrave.

Kantola, J. and Nousiainen, K. (2012) 'The European Union: initiator of a new European anti-discrimination regime?', in A. Krizsán, H. Skjeie and J. Squires (eds.), Institutionalizing Intersectionality: The Changing Nature of European Equality Regimes, London: Springer, 33-58.

Kantola, J. (2010) Gender and the European Union, Basingstoke: Palgrave.

Karamessini, M. and Rubery, J. (2014) 'The challenge of austerity for equality. A consideration of eight European countries in the crisis', Revue de l'OFCE, 2, 133, 15-39. 
Lacey, N. (1987) 'Legislation against sex discrimination: questions from a feminist perspective', Journal of Law and Society, 14, 4, 411-21.

MacKinnon, C. (1998) 'Difference and dominance: on sex discrimination', in A. Phillips (ed.), Feminisms and Politics, Oxford: Oxford University Press, 295-313.

MacRae, H. (2010) 'The EU as a gender equal polity: myths and realities', Journal of Common Market Studies, 48, 1, 155-74.

Masselot, A., Caracciolo di Torella, E. and Burri, S. (2012) Thematic Report of the European Network of Legal Experts in the Field of Gender Equality "Fighting Discrimination on the Grounds of Pregnancy, Maternity and Parenthood - The Application of EU and National Law in Practice in 33 European Countries", Publication of the European Commission, http://ec.europa.eu/justice/genderequality/files/your_rights/discrimination__pregnancy_maternity_parenthood_final.en.pdf [accessed 08.11.2017].

Masselot, A. and Maymont, A. (2015) 'Gendering economic and financial governance through positive action measures: compatibility of the French real equality measure under the European Union framework', Maastricht Journal of European and Comparative Law, 22, 1, 57-80.

Masselot, A. and Brand, T. (2015) 'Diversity, quotas and compromise in the boardroom: can New Zealand adopt a legislation to tackle gender imbalance in economic decision making?', New Zealand Universities Law Review, 26, 1-23.

PA (2011) 'EU maternity leave plans rejected', The Independent, 17 June, http://www.independent.co.uk/ news/world/europe/eu-maternity-leave-plans-rejected-2299051.html [accessed 07.11.2016].

Plomien, A. (2018) 'EU Social and Gender Policy beyond Brexit: Towards the European Pillar of Social Rights', Social Policy \& Society, doi:10.1017/S1474746417000471.

Reding, V. (2011) Women on the Board Pledge for Europe, IP/11/242 and MEMO11/124.

Sealy, R. and Vinnicombe, S. (2013) The Female FTSE Board Report 2013, Cambera: Cranfield School of Management, http://www.som.cranfield.ac.uk/som/dinamic-content/media/Research/ Research\%20Centres/CICWL/FTSEReport2013.pdf> [accessed 08.11.2017].

Syrpis, P. (2017) 'European Union (Withdrawal) Bill: paving the way towards a very uncertain future', University of Bristol Law School Blog, http://legalresearch.blogs.bris.ac.uk/2017/07/ european-union-withdrawal-bill-paving-the-way-towards-a-very-uncertain-future/\#more-734 [accessed 08.11.2017].

UK Parliament (2017) European Union (Withdrawal) Bill [HC], Bill 5, 2017-19, https://publications.parliament.uk/pa/bills/cbill/2017-2019/0005/18005.pdf [accessed 08.11.2017].

Van der Vleuten, A. (2007) The Price of Gender Equality: Member States and Governance in the European Union, London and New York: Routledge.

Walby, S. (2004) 'The European Union and gender equality: emergent varieties of gender regime', Social Politics, 11, 1, 4-29.

Walby, S. (2015) Crisis, Cambridge: Polity Press.

Woodward, A. and van der Vleuten, A. (2014) 'EU and the export of gender equality norms: myths and facts', in A. Van der Vleuten, A. van Eerdewijk and C. Roggeband (eds.), Gender Equality Norms in Regional Governance: Transnational Dynamics in Europe, South America and Southern Africa, Palgrave: Basingstoke, 67-92.

Woodward, A. (2003) 'Building velvet triangles: gender and informal governance', in T. Christiansen and S. Piattoni (eds.), Informal governance in the European Union, Edward Elgar: Cheltenham, 76-93. 